\title{
The Effect of Principal's Competence and Community Participation on the Quality of Educational Services
}

\author{
Deni Zulaiha \\ SD Negeri 68 Palembang, Indonesia \\ e-mail: denizulaiha62@gmail.com \\ Bukman Lian \\ Universitas PGRI Palembang, Indonesia \\ e-mail: drbukmanlian@univpgri-palembang.ac.id \\ Mulyadi \\ Universitas PGRI Palembang, Indonesia \\ e-mail:mulyadi@univpgri-palembang.ac.id
}

Article History: Received on 16 July 2020, Revised on 21 July 2020, Published on 27 July 2020

\begin{abstract}
This research was conducted at Public Elementary School 68 Palembang with 34 teachers as respondents in the study sample. In this study there are three research variables consisting of two independent variables Principal Competence $\left(\mathrm{X}_{1}\right)$ and Community Participation $\left(\mathrm{X}_{2}\right)$, and one dependent variable Quality of Educational Services (Y). The extent to which the realization and role of community participation in education depends on the understanding of the community itself in education, and depends on the ability of the school. Quality education services are educational services that are in accordance with the plan and achieve the goals set and can meet the expectations and needs of customers. The results obtained in this study illustrate that the quality of educational services in Public Elementary School 68 Palembang is very good and can meet customer needs.
\end{abstract}

Keywords: Principal's Competence; Community Participation; Quality of Educational Services

\section{A. Introduction}

In this day and age schools are competing to improve the quality of education services to create or produce quality students. To realize this must be supported by competent school principals, educational staff who carry out teaching and learning activities namely teachers, reliable administrative administration, adequate infrastructure and community participation. According to Kristiawan, et al (2017: 32), Elementary School is a social organization that has set goals. The main purpose of primary schools is to provide quality education to students in elementary schools.

School as a formal institution is an organization that has a vision, mission and goals to be achieved through the process and empowerment of the elements that exist in the organization. The elements that exist in the organization starting from the teacher, students, academic programs, and supporting facilities without anyone empowering or managing it is something that is impossible will run automatically in synergy to be able to achieve the vision, mission, 
goals that have been determined. For this reason, in each education unit a principal is needed as the manager.

According to the Law 2003 National Education System article 1 paragraph 1 stated that the learning process so that students actively develop their potential, intelligence, noble character, and skills, which are needed by themselves, the community, the nation and the State. Starting from the goal that every educational institution should move from the beginning to the end until the goal point of an educational process, according to Suderadjat (2005) realizing the occurrence of learning as a process of actualizing the potential of students into competencies that can be utilized or used in life.

According to Syafaruddin (2002), in the Indonesian national education system schools have a strategic role as institutions that provide educational activities. Therefore, it is clear that the school has a heavy important task. It is hard because it must always fight against various weaknesses, threats and challenges in order to harmonize the programs of activities that are realized with the dynamics of the rapid development of science and technology. According to Nawawi (1982: 27) the role of schools as educational institutions is to develop the human potential of children to be able to carry out the tasks of life as human beings, both individually and members of society. Activities to develop this potential must be carried out in a planned, directed and systematic manner in order to achieve certain goals. Therefore, it can be said that the function of the school is to continue, maintain and develop the culture of a society that organizes schools as educational institutions.

Seeing the position of the school is so important Syafaruddin (2002: 88) said that the school became the center of community dynamics. The existence of a school becomes a social institution that determines children's personal development and the socialization and culture of a nation.

Behind the function and role of schools that are essential for the personal development of students, the community and the nation, and the high expectations of the community towards schools there is a reality that is far from what is expected by the community. In other words school institutions are still of low quality and have not been able to meet the expectations of the community. This is reflected in the low quality of school graduates expressed by the large number of unemployed school graduates and the emergence of symptoms of mental and moral decline in daily life. Even in everyday reality there is an increase in crime as a reflection of the still low quality of our nation's human resources. The above description is in accordance with that stated by Suderadjat (2005: 4) that school graduates, especially in Indonesia, are judged to be of poor quality compared to other countries.

Syafaruddin (2002: 19) mentions that the world of education has not fully met people's expectations. This phenomenon is marked by the low quality of graduates, solving incomplete educational problems, or tends to be patchy, even more project orientation. As a result, often the results of education disappoint the community. They continue to question the relevance of education to the needs of society in the dynamics of economic, political, social and cultural life. The quality of education graduates is not in accordance with the needs of the labor market and development; both industry, banking, telecommunications, and the labor market in other sectors that tend to challenge the existence of schools. Even human resources prepared through education as the next generation have not been fully satisfactory when viewed in terms of morals, morals, and national identity in the diversity of national culture. 
Departing from the reality above, inevitably efforts must be made to improve the success of schools so that they become effective and productive educational institutions. The realization of an effective and productive school is a characteristic that the school is successful in carrying out and carrying out its duties and functions. Syafaruddin (2002: 97) argues that successful organizations are organizations whose effectiveness and productivity are getting higher and higher. Therefore, Siagian (2002: 1) argues that the productivity of an organization must always be strived to be continuously improved, regardless of its purpose, mission, type, structure, and size. This axiom applies to all types of organizations. So, in accordance with this opinion, of course including educational organizations or schools must make various efforts to improve their effectiveness and productivity, so that what is expected can be achieved optimally.

To see the success of a school must be measured by the criteria as stated Daryanto (2006: 17) that there are four objectives, namely: Production effectiveness, efficiency, ability to adjust, and job satisfaction, can be used as criteria for determining the success of a school. Production effectiveness, which means producing a number of graduates in accordance with the demands of the applicable curriculum.

Examining developments in schools and school graduates as a reflection of the quality of education services compared to Presidential Regulation No. 19 of 2005 there were still many gaps between expectations and reality. This can be seen from the still low quality of graduate competencies, the lack of professionalism of teachers in managing learning, there are still many teachers who have not yet attained S1 academic qualifications, the still low relevance of education to the needs of the community.

In other words, the phenomenon that is seen in school education institutions is currently still low in quality of service. The quality of education services is reflected by a measure of the level of output of a program that is the responsibility of the school. Thus the importance of the problem of the quality of education services so that they have a very close relationship in efforts to improve the quality of education. To improve the quality of education services in schools must be supported by various stakeholders including the community. Hadiyanto (2004: 85) mentions 1) the community's role in improving the quality of education services which includes planning, supervision and evaluation of educational programs through the education board and school committee; 2) school committees play a role in improving the quality of services and provide consideration, direction and support of personnel, facilities and infrastructure as well as education supervision at the education unit level. Komariah and Triatna (2006: 5) say that the decision on how the school works is based on community participation in order to foster a sense of ownership for all school interests. From the descriptions above it is clear that in order to improve the quality of education services in schools, active participation from the community is needed. With optimal cooperation, various problems and obstacles faced will be more easily overcome.

Harmonious relationships and cooperation in synergy between the school and the community will not just happen without effort. Mulyasa (2006: 163) says that such links can occur if the principal is active and can build mutually beneficial relationships. This statement implies that a school principal must have the toughness in carrying out his duties in order to improve the quality of education services. 
The principal has a decisive position in achieving success in school. If the principal is able to empower all the existing potential, then it will arrive towards the goals that are aspired, and vice versa if the principal does not have the ability it will create a downturn. Thus it appears that the competency of school principals is influential on their performance so it is logical that the low quality of education services in schools is one of them due to the competencies of principals who have not met the criteria. Mulyasa (2006: 158) stated that school failure and success are largely determined by the school principal, because the school principal is the controller and determinant of the direction the school intends to take toward its goals.

Based on the descriptions and problems above that reveal how important the role of community involvement and the competence of principals to improve the quality of education services. The authors deem it is necessary to conduct research related to the above problems.

\section{B. Methods}

This research conducted by the author is included in non-experimental quantitative research, namely research involving cause and effect between the independent variable and the dependent variable. The circumstances described in this study are the facts that occur at the present time. Therefore this research is classified into descriptive research. Trisnamansyah (2007: 13) suggests that descriptive research describes the phenomena that exist today, using numbers to provide characteristics to the individual or group under study. This study accesses the nature of the conditions that exist today, so the aim is limited to the distribution of the characteristics of things as they are.

In collecting data examined using questionnaires, this type of research is including survey research. As explained by Trisnamansyah (2007: 13) that Survey is a type of research in which data collection is carried out using a questionnaire, which is a list of questions to collect answers from a number of respondents.

In the final stage the results of this study look for the level of relationship between the independent variables namely the competency of the principal and community participation in the administration of education $\left(\mathrm{X}_{1}\right.$ and $\left.\mathrm{X}_{2}\right)$ with the dependent variable namely the quality of educational services (Y). Thus this research belongs to the correlational research method. To measure the degree of relationship between variables using statistical correlation analysis. Regarding correlational research Trisnamansyah (2007: 13) explains as follows correlational research related to the measurement of institutions between two or more variables. This type of research uses correlation statistical analysis to measure relationships. The purpose of this study is to detect the extent to which variations in a factor are related to variations in one or more other factors based on the correlation coefficient. Relationship measures are statements about the degree of association between the variables studied. The correlation can be positive or negative. A positive correlation means the higher the value of one variable (the independent variable) followed by the higher the value of the other variable (the dependent variable). While the negative correlation if the higher the value of one variable is followed by the lower value of the other variables.

In short, the method used in this study is descriptive research methods and survey research methods with quantitative and correlational approaches. We used to determine the effect of the three variables, principal's leadership $\left(\mathrm{X}_{1}\right)$, work motivation $\left(\mathrm{X}_{2}\right)$ and dependent variable is teacher work discipline (Y). The population in this study were all Madrasah Tsanawiyah Negeri as Ogan Ilir 2 schools including 110 principals and all teachers in Madrasah 
Volume 1 (1) 2020

E-ISSN: 2723-6919

Tsanawiyah Negeri totaling 110 out of 2 schools. The sampling in this study will use the Slovin formula (Anggraini and Wahyudi, 2017: 17):

$$
\begin{aligned}
& \begin{array}{l}
N \\
\mathrm{n}= \\
1+N(\mathrm{~d})^{2}
\end{array} \\
& \text { Where: } \\
& \mathrm{n}=\text { sample size } \\
& \mathrm{N}=\text { population size } \\
& \mathrm{d}=\text { selected error rate }(10 \%) .
\end{aligned}
$$

The instrument used to obtain data on the two variables (Principal Leadership and Teacher Work Discipline) is the same using a questionnaire instrument that is measured by a Likert scale consisting of 4 alternative answers given a score of 1-4 for positive and negative statements. The calculation that the author uses in this study is to use the Statistical Package for the Social Science (SPSS) version 12.0. The minimum criteria for statement items

\begin{tabular}{|c|c|c|c|c|c|c|c|c|c|c|c|c|}
\hline \multicolumn{13}{|c|}{ Principal Leadership } \\
\hline \multicolumn{6}{|c|}{ Respondent's Response } & \multirow[b]{2}{*}{ Frequency } & \multicolumn{5}{|c|}{ Percentage } & \multirow{2}{*}{$\%$} \\
\hline Item & 1 & 2 & 3 & 4 & 5 & & 1 & 2 & 3 & 4 & 5 & \\
\hline \multicolumn{13}{|c|}{ The principal is a role model } \\
\hline 1 & 0 & 2 & 10 & 21 & 12 & 45 & 0 & 0 & 22 & 31 & 47 & 100 \\
\hline Total & 0 & 2 & 10 & 21 & 12 & 45 & 0 & 0 & 22 & 31 & 47 & 100 \\
\hline \multicolumn{13}{|c|}{ The principal is respected by fellow school residents } \\
\hline 2 & 0 & 0 & 5 & 14 & 26 & 45 & 0 & 0 & 11 & 31 & 58 & 100 \\
\hline 3 & 0 & 2 & 12 & 14 & 17 & 45 & 0 & 4 & 27 & 31 & 38 & 100 \\
\hline Total & 0 & 2 & 17 & 28 & 43 & 90 & 0 & 2 & 19 & 31 & 48 & 100 \\
\hline \multicolumn{13}{|c|}{ The principal is able to make the best decisions } \\
\hline 4 & 0 & 3 & 6 & 11 & 25 & 45 & 0 & 7 & 13 & 24 & 56 & 100 \\
\hline 5 & 0 & 2 & 6 & 19 & 18 & 45 & 0 & 4 & 13 & 42 & 40 & 100 \\
\hline Total & 0 & 5 & 12 & 30 & 43 & 90 & 0 & 6 & 13 & 33 & 48 & 100 \\
\hline \multicolumn{13}{|c|}{ Inspirational Motivation } \\
\hline 6 & 0 & 2 & 6 & 18 & 19 & 45 & 0 & 4 & 13 & 40 & 42 & 100 \\
\hline 7 & 0 & 2 & 10 & 13 & 20 & 45 & 0 & 4 & 22 & 29 & 44 & 100 \\
\hline 8 & 0 & 0 & 5 & 11 & 29 & 45 & 0 & 0 & 11 & 24 & 64 & 100 \\
\hline 9 & 0 & 5 & 6 & 9 & 25 & 45 & 0 & 11 & 13 & 20 & 56 & 100 \\
\hline 10 & 0 & 2 & 5 & 19 & 19 & 45 & 0 & 4 & 11 & 42 & 42 & 100 \\
\hline 11 & 0 & 0 & 6 & 19 & 20 & 45 & 0 & 0 & 13 & 42 & 44 & 100 \\
\hline 12 & 0 & 0 & 13 & 14 & 18 & 45 & 0 & 0 & 29 & 31 & 40 & 100 \\
\hline Total & 0 & 11 & 51 & 103 & 150 & 315 & 0 & 3 & 16 & 33 & 48 & 100 \\
\hline \multicolumn{13}{|c|}{ Intellectual stimulation } \\
\hline 13 & 0 & 0 & 8 & 18 & 19 & 45 & 0 & 0 & 18 & 40 & 42 & 100 \\
\hline 14 & 0 & 1 & 4 & 15 & 25 & 45 & 0 & 2 & 9 & 33 & 56 & 100 \\
\hline
\end{tabular}
received is if $r_{\text {count }}>r_{\text {table }}$, then statement items are considered valid. Conversely, if $r_{\text {count }}$ $<\mathrm{r}_{\text {table }}$, then the statement item is considered invalid, dropped or not used.

\section{Results and Discussion}

Table below is the frequency distribution of the Principal Leadership variable $\left(\mathrm{X}_{1}\right)$ on each item for each of the existing indicators.

Tabel 1. Distribution of Frequency Variable Principal's Leadership $\left(\mathrm{X}_{1}\right)$ 


\begin{tabular}{|c|c|c|c|c|c|c|c|c|c|c|c|c|}
\hline \multicolumn{13}{|c|}{ Principal Leadership } \\
\hline \multicolumn{6}{|c|}{ Respondent's Response } & \multirow[b]{2}{*}{ Frequency } & \multicolumn{5}{|c|}{ Percentage } & \multirow{2}{*}{$\%$} \\
\hline Item & 1 & 2 & 3 & 4 & 5 & & 1 & 2 & 3 & 4 & 5 & \\
\hline 15 & 0 & 0 & 10 & 14 & 21 & 45 & 0 & 0 & 22 & 31 & 47 & 100 \\
\hline 16 & 0 & 4 & 5 & 11 & 25 & 45 & 0 & 9 & 11 & 24 & 56 & 100 \\
\hline 17 & 0 & 0 & 7 & 20 & 18 & 45 & 0 & 0 & 16 & 44 & 40 & 100 \\
\hline Total & 0 & 5 & 34 & 78 & 108 & 225 & 0 & 2 & 15 & 35 & 48 & 100 \\
\hline \multicolumn{13}{|c|}{ Individual Consideration } \\
\hline 18 & 0 & 6 & 10 & 5 & 24 & 45 & 0 & 13 & 22 & 11 & 53 & 100 \\
\hline 19 & 0 & 0 & 12 & 17 & 16 & 45 & 0 & 0 & 27 & 38 & 36 & 100 \\
\hline 20 & 0 & 0 & 0 & 15 & 30 & 45 & 0 & 0 & 0 & 33 & 67 & 100 \\
\hline 21 & 0 & 6 & 11 & 23 & 5 & 45 & 0 & 13 & 24 & 51 & 11 & 100 \\
\hline 22 & 0 & 11 & 0 & 15 & 19 & 45 & 0 & 24 & 0 & 33 & 42 & 100 \\
\hline Total & 0 & 23 & 33 & 75 & 94 & 225 & 0 & 10 & 15 & 33 & 42 & 100 \\
\hline
\end{tabular}

Based on the above table, it can be seen that the item number on the questionnaire is 22 items starting number 1 - 22, while the respondent's answer which consists of 5 options namely value 1 is a totally disagree answer, value 2 answers disagree, value 3 answers are doubtfuldoubt, the value of 4 answers agree and the value of 5 answers strongly agree. The percentage of the table above is obtained from the number of questionnaire answers divided by total respondents multiplied by $100 \%$, so that the percentage of answers obtained for each item is obtained. The above table clearly shows that the principal's leadership on the principal indicator is a role model / example shows $0 \%$ of respondents answered strongly disagree, $0 \%$ answered disagreed, 22\% agreed doubtful, 31\% answered agreed and 47\% answered strongly agree. The school principal indicator respected by fellow school members shows $0 \%$ of respondents answered strongly disagree, $2 \%$ of respondents answered disagree, $19 \%$ of respondents answered doubtfully, $31 \%$ of respondents answered agree and $48 \%$ answered strongly agree.

The school principal indicator is able to make the best decision showing $0 \%$ of respondents answered strongly disagree, $6 \%$ answered disagreed, $13 \%$ agreed doubtfully, $33 \%$ answered agreed and $48 \%$ answered strongly agree. On the motivational indicators of inspirational school principals show $0 \%$ of respondents answered strongly disagree, 3\% answered disagreed, $16 \%$ answered doubtful, $33 \%$ answered agreed and $48 \%$ answered strongly agree.

The principal's intellectual indicator shows that $0 \%$ of respondents answered strongly disagree, $2 \%$ answered disagreed, 15\% answered doubt, 35\% answered agreed and 48\% answered strongly agree. the principal's leadership on the indicator of caring for individual teachers showed $0 \%$ of respondents answered strongly disagree, $10 \%$ answered disagreed, $15 \%$ maintained doubt, $33 \%$ answered agreed and $42 \%$ answered strongly agree. The description of the values above can be seen in the table below.

Table 2. Statistics Descriptive Principal's Leadership

\begin{tabular}{|c|c|c|}
\hline \multicolumn{3}{|c|}{ Statistics } \\
\hline \multicolumn{3}{|c|}{ Principal's Leadership } \\
\hline $\mathrm{N}$ & Valid & 45 \\
\hline & Missing & 0 \\
\hline & & 92,67 \\
\hline & ror of Mean & 1,162 \\
\hline
\end{tabular}




\begin{tabular}{|l|r|}
\hline Median & 94,00 \\
\hline Mode & $96^{2}$ \\
\hline Std. Deviation & 7,793 \\
\hline Variance & 60,727 \\
\hline Skewness & $-1,209$ \\
\hline Std. Error of Skewness &, 354 \\
\hline Kurtosis &, 729 \\
\hline Std. Error of Kurtosis &, 695 \\
\hline Range & 30 \\
\hline Minimum & 73 \\
\hline Maximum & 103 \\
\hline Sum & 4170 \\
\hline
\end{tabular}

The influence of the principal's leadership shows that the average value reached 92.67 with a standard deviation of 7.793. Work motivation variables were also answered by respondents with five answer options to find out the percentage of respondents' answers. The following table is the frequency distribution of work motivation acquisition variables $\left(\mathrm{X}_{2}\right)$.

Tabel 3. Distribution of Frequency Variable Work Motivation $\left(\mathbf{X}_{2}\right)$

\begin{tabular}{|c|c|c|c|c|c|c|c|c|c|c|c|c|}
\hline \multicolumn{13}{|c|}{ Work Motivation } \\
\hline \multicolumn{6}{|c|}{ Respondent's Response } & \multirow[b]{2}{*}{ Frequency } & \multicolumn{5}{|c|}{ Percentage } & \multirow{2}{*}{$\%$} \\
\hline Item & 1 & 2 & 3 & 4 & 5 & & 1 & 2 & 3 & 4 & 5 & \\
\hline \multicolumn{13}{|c|}{ Internal Motivation } \\
\hline 1 & 0 & 2 & 10 & 17 & 16 & 45 & 0 & 4 & 22 & 38 & 36 & 100 \\
\hline 2 & 0 & 0 & 4 & 17 & 24 & 45 & 0 & 0 & 9 & 38 & 53 & 100 \\
\hline 3 & 0 & 1 & 8 & 16 & 20 & 45 & 0 & 2 & 18 & 36 & 44 & 100 \\
\hline 4 & 0 & 4 & 4 & 13 & 24 & 45 & 0 & 9 & 9 & 29 & 53 & 100 \\
\hline 5 & 0 & 2 & 8 & 16 & 19 & 45 & 0 & 4 & 18 & 36 & 42 & 100 \\
\hline 6 & 0 & 1 & 4 & 16 & 24 & 45 & 0 & 2 & 9 & 36 & 53 & 100 \\
\hline 7 & 0 & 0 & 9 & 16 & 20 & 45 & 0 & 0 & 20 & 36 & 44 & 100 \\
\hline 8 & 0 & 4 & 3 & 14 & 24 & 45 & 0 & 9 & 7 & 31 & 53 & 100 \\
\hline 9 & 0 & 2 & 7 & 12 & 24 & 45 & 0 & 4 & 16 & 27 & 53 & 100 \\
\hline 10 & 0 & 2 & 5 & 17 & 21 & 45 & 0 & 4 & 11 & 38 & 47 & 100 \\
\hline 11 & 0 & 0 & 8 & 12 & 25 & 45 & 0 & 0 & 18 & 27 & 56 & 100 \\
\hline 12 & 0 & 2 & 6 & 17 & 20 & 45 & 0 & 4 & 13 & 38 & 44 & 100 \\
\hline Total & 0 & 20 & 76 & 183 & 261 & 540 & 0 & 4 & 14 & 34 & 48 & 100 \\
\hline \multicolumn{13}{|c|}{ External Motivation } \\
\hline 13 & 0 & 2 & 10 & 17 & 16 & 45 & 0 & 4 & 22 & 38 & 36 & 100 \\
\hline 14 & 0 & 0 & 5 & 19 & 21 & 45 & 0 & 0 & 11 & 42 & 47 & 100 \\
\hline 15 & 0 & 0 & 10 & 10 & 25 & 45 & 0 & 0 & 22 & 22 & 56 & 100 \\
\hline 16 & 0 & 2 & 10 & 17 & 16 & 45 & 0 & 4 & 22 & 38 & 36 & 100 \\
\hline 17 & 0 & 2 & 6 & 16 & 21 & 45 & 0 & 4 & 13 & 36 & 47 & 100 \\
\hline 18 & 0 & 2 & 10 & 17 & 16 & 45 & 0 & 4 & 22 & 38 & 36 & 100 \\
\hline 19 & 0 & 0 & 10 & 6 & 29 & 45 & 0 & 0 & 22 & 13 & 64 & 100 \\
\hline 20 & 0 & 6 & 10 & 16 & 13 & 45 & 0 & 13 & 22 & 36 & 29 & 100 \\
\hline 21 & 0 & 4 & 4 & 21 & 16 & 45 & 0 & 9 & 9 & 47 & 36 & 100 \\
\hline Total & 0 & 18 & 75 & 139 & 173 & 405 & 0 & 4 & 19 & 34 & 43 & 100 \\
\hline
\end{tabular}


Volume 1 (1) 2020

E-ISSN: 2723-6919

Based on the table above, it can be seen that the item number on the questionnaire is 21 items starting from numbers 1-10, while the respondent's answer consists of 5 options namely value 1 is a totally disagree answer, value 2 answers disagree, value 3 answers are doubtful- doubt, the value of 4 answers agree and the value of 5 answers strongly agree. The percentage of the table above is obtained from the number of questionnaire answers divided by total respondents multiplied by $100 \%$, so that the percentage of answers obtained for each item is obtained.

From the table above it is clear that work motivation on internal motivation indicators shows $0 \%$ of respondents answered strongly disagree, $4 \%$ answered disagreed, $14 \%$ answered doubtful, 34\% answered agreed and $48 \%$ answered strongly agree. On the external motivation indicator, respondents' answers were $0 \%$ answered strongly disagree, $4 \%$ answered disagreed, 19\% answered doubtful, 34\% answered agreed and 43\% answered strongly agree.

From the analysis of the answers given to respondents who were sampled in this study, obtained descriptive statistical data regarding work motivation as follows.

Table 4. Statistics Descriptive Work Motivation

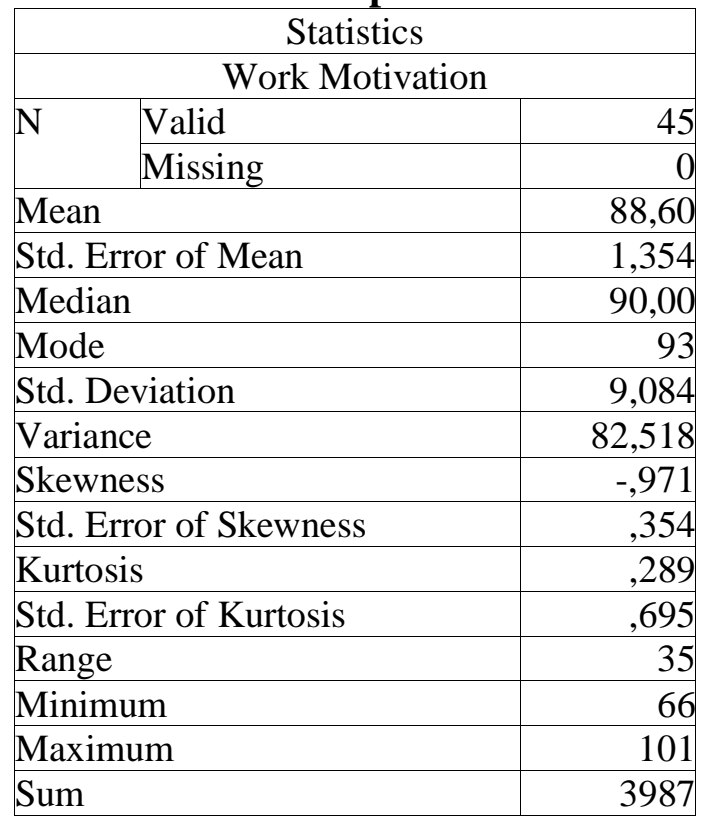

From the table above, it can be seen that the influence of work motivation on teacher's discipline with an average score of 88.60 with a standard deviation of 9.084 . The teacher discipline variable has 23 statement items with five alternative answers chosen by the respondent. The results of these answers can be seen in table below.

Tabel 5. Distribution of Frequency Variable Teacher's Discipline (Y)

\begin{tabular}{|c|c|c|c|c|c|c|c|c|c|c|c|c|}
\hline \multicolumn{13}{|c|}{ Teacher's Discipline } \\
\hline \multicolumn{6}{|c|}{ Respondent's Response } & \multirow[b]{2}{*}{ Frequency } & \multicolumn{5}{|c|}{ Percentage } & \multirow{2}{*}{$\%$} \\
\hline Item & 1 & 2 & 3 & 4 & 5 & & 1 & 2 & 3 & 4 & 5 & \\
\hline \multicolumn{13}{|c|}{ Discipline } \\
\hline 1 & 0 & 2 & 10 & 21 & 12 & 45 & 0 & 4 & 22 & 47 & 27 & 100 \\
\hline 2 & 0 & 8 & 1 & 24 & 12 & 45 & 0 & 18 & 2 & 53 & 27 & 100 \\
\hline
\end{tabular}




\begin{tabular}{|c|c|c|c|c|c|c|c|c|c|c|c|c|}
\hline \multicolumn{13}{|c|}{ Teacher's Discipline } \\
\hline \multicolumn{6}{|c|}{ Respondent's Response } & \multirow[b]{2}{*}{ Frequency } & \multicolumn{5}{|c|}{ Percentage } & \multirow{2}{*}{$\%$} \\
\hline Item & 1 & 2 & 3 & 4 & 5 & & 1 & 2 & 3 & 4 & 5 & \\
\hline 3 & 0 & 8 & 1 & 14 & 22 & 45 & 0 & 18 & 2 & 31 & 49 & 100 \\
\hline 4 & 0 & 0 & 11 & 24 & 10 & 45 & 0 & 0 & 24 & 53 & 22 & 100 \\
\hline 5 & 0 & 0 & 8 & 17 & 20 & 45 & 0 & 0 & 18 & 38 & 44 & 100 \\
\hline 6 & 0 & 2 & 8 & 16 & 19 & 45 & 0 & 4 & 18 & 36 & 42 & 100 \\
\hline Total & 0 & 20 & 39 & 116 & 95 & 270 & 0 & 7 & 14 & 43 & 35 & 100 \\
\hline \multicolumn{13}{|c|}{ Work Awareness } \\
\hline 7 & 0 & 7 & 1 & 6 & 31 & 45 & 0 & 16 & 2 & 13 & 69 & 100 \\
\hline 8 & 0 & 4 & 18 & 18 & 5 & 45 & 0 & 9 & 40 & 40 & 11 & 100 \\
\hline 9 & 0 & 2 & 6 & 25 & 12 & 45 & 0 & 4 & 13 & 56 & 27 & 100 \\
\hline 10 & 0 & 8 & 2 & 23 & 12 & 45 & 0 & 18 & 4 & 51 & 27 & 100 \\
\hline 11 & 0 & 2 & 8 & 16 & 19 & 45 & 0 & 4 & 18 & 36 & 42 & 100 \\
\hline 12 & 0 & 2 & 14 & 16 & 13 & 45 & 0 & 4 & 31 & 36 & 29 & 100 \\
\hline 13 & 0 & 2 & 8 & 16 & 19 & 45 & 0 & 4 & 18 & 36 & 42 & 100 \\
\hline 14 & 0 & 3 & 6 & 17 & 19 & 45 & 0 & 7 & 13 & 38 & 42 & 100 \\
\hline Total & 0 & 30 & 63 & 137 & 130 & 360 & 0 & 8 & 18 & 38 & 36 & 100 \\
\hline \multicolumn{13}{|c|}{ Compliance with Regulations } \\
\hline 15 & 0 & 2 & 8 & 16 & 19 & 45 & 0 & 4 & 18 & 36 & 42 & 100 \\
\hline 16 & 0 & 0 & 9 & 23 & 13 & 45 & 0 & 0 & 20 & 51 & 29 & 100 \\
\hline 17 & 0 & 3 & 3 & 11 & 28 & 45 & 0 & 7 & 7 & 24 & 62 & 100 \\
\hline 18 & 0 & 7 & 3 & 6 & 29 & 45 & 0 & 16 & 7 & 13 & 64 & 100 \\
\hline 19 & 0 & 6 & 10 & 18 & 11 & 45 & 0 & 13 & 22 & 40 & 24 & 100 \\
\hline 20 & 0 & 0 & 11 & 5 & 29 & 45 & 0 & 0 & 24 & 11 & 64 & 100 \\
\hline 21 & 0 & 3 & 6 & 26 & 10 & 45 & 0 & 7 & 13 & 58 & 22 & 100 \\
\hline 22 & 0 & 2 & 7 & 18 & 18 & 45 & 0 & 4 & 16 & 40 & 40 & 100 \\
\hline 23 & 0 & 7 & 9 & 15 & 14 & 45 & 0 & 16 & 20 & 33 & 31 & 100 \\
\hline Total & 0 & 30 & 66 & 138 & 171 & 405 & 0 & 7 & 16 & 34 & 42 & 100 \\
\hline
\end{tabular}

From the above table it is clear that the teacher discipline on the timeliness indicator shows $0 \%$ of respondents answered strongly disagree, $7 \%$ answered disagreed, $14 \%$ answered doubtfully, $43 \%$ answered agreed and $35 \%$ answered strongly agree. In the indicator of work awareness shows $0 \%$ of respondents answered strongly disagree, $8 \%$ answered disagreed, $18 \%$ of respondents answered doubtfully, 38\% of respondents answered agree and $36 \%$ answered strongly agree.

The compliance indicator shows that $0 \%$ answered strongly disagree, $7 \%$ answered disagree, $16 \%$ answered doubtful, $34 \%$ answered agreed and $42 \%$ answered strongly agree. From the analysis of the answers given to the respondents who were sampled in this study, obtained descriptive statistical data regarding teacher discipline as follows.

Table 6. Statistics Descriptive Teacher's Discipline

\begin{tabular}{|c|c|}
\hline & \\
\hline \multicolumn{2}{|c|}{ Teacher's Discipline } \\
\hline Valid & 45 \\
\hline Missing & \\
\hline Mean & 93,51 \\
\hline Std. Error of Mean & 1,451 \\
\hline Median & 96,00 \\
\hline
\end{tabular}




\begin{tabular}{|l|r|}
\hline Mode & 99 \\
\hline Std. Deviation & 9,737 \\
\hline Variance & 94,801 \\
\hline Skewness & $-1,276$ \\
\hline Std. Error of Skewness &, 354 \\
\hline Kurtosis & 1,246 \\
\hline Std. Error of Kurtosis &, 695 \\
\hline Range & 44 \\
\hline Minimum & 65 \\
\hline Maximum & 109 \\
\hline Sum & 4208 \\
\hline
\end{tabular}

From the table above it can be seen that the variable of teacher discipline with an average value reaches 93.51 with a standard deviation of 9.737. Testing the Multiple Correlation Coefficient (Simultaneous Hypothesis) is used to determine whether the regression coefficient has a significant effect or not together between the independent variables $\left(\mathrm{X}_{1}\right.$, and $\mathrm{X}_{2}$ ) on the dependent variable (Y). If Sig. $>\alpha(0.05)$, then the regression coefficient is not significant. If Sig. $<\alpha(0.05)$, then the regression coefficient is significant. Multiple correlation analysis is often called the simultaneous hypothesis test or the f-test shown in the table below.

Based on the $\mathrm{f}_{\text {count }}$ in the table above, it is known 82.468.

Hypothesis test: $f_{\text {count }} \geq f_{\text {table }}=$ Ha Accepted

$\mathrm{f}_{\text {count }} \leq \mathrm{f}_{\text {table }}=$ Ha Rejected

$\mathrm{f}_{\text {table }}$ obtained for 3,070

Based on the explanation above it is known that $f_{\text {count }}=82.468$ and $f_{\text {table }}=3.070$ where $f_{\text {count }}>$ $\mathrm{f}_{\text {table }}$ which means Ha is accepted or in other words there is an influence of school leadership and work motivation on teacher discipline.

Regression efficiency is often known as partial hypothesis testing or testing the effect of each independent variable on the dependent variable or the influence of the principal's leadership variable $\left(\mathrm{X}_{1}\right)$ to the teacher's discipline variable $(\mathrm{Y})$, work motivation variable $\left(\mathrm{X}_{2}\right)$ to the teacher's discipline (Y), by looking $\mathrm{t}$ value in the existing output. The test results can be seen in the table below.

Table 7. T-Test Analysis

\begin{tabular}{|c|c|c|c|c|c|c|}
\hline \multicolumn{7}{|c|}{ Coefficients } \\
\hline & \multirow[t]{2}{*}{ Model } & \multicolumn{2}{|c|}{ Unstandardized Coefficients } & $\begin{array}{l}\text { Standardized } \\
\text { Coefficients }\end{array}$ & \multirow[b]{2}{*}{$\mathrm{t}$} & \multirow[b]{2}{*}{ Sig. } \\
\hline & & $\mathrm{B}$ & Std. Error & Beta & & \\
\hline \multirow[t]{3}{*}{1} & (Constant) & $-2,544$ & 8,203 & &,- 310 &, 758 \\
\hline & $\begin{array}{l}\text { Principal's } \\
\text { Leadership }\end{array}$ & ,330 & 120 & 264 & 2,743 & ,009 \\
\hline & Work Motivation & ,739 & 103 & 690 & 7,171 & 000 \\
\hline \multicolumn{7}{|c|}{ a. Dependent Variable: Teacher's Discipline } \\
\hline
\end{tabular}


This is in line with the results of Hijri's research (2018) which concluded that there was a significant influence between the headmaster's leadership on the work discipline of Islamic Religious Education teachers in the 060794 State Primary School Medan Area, the effect of which was moderate or sufficient. Because with responsible and wise leadership possessed by the principal has made the teacher work with good discipline and timely in doing each of his tasks so that the effectiveness of learning can be achieved.

While Sari's research (2010), the results of descriptive analysis show the average performance of accounting teachers in the sufficient category, the headmaster's leadership in the good category and the teacher's work discipline in the sufficient category. The results of regression analysis with SPSS 17.0 show there is a partial effect between the leadership of the principal on the performance of accounting teachers by $21.16 \%$, there is a partial effect between the teacher's work discipline on the performance of accounting teachers by $25.20 \%$, and there is a simultaneous influence between leadership school principals and teacher work discipline on the performance of accounting teachers by $44.30 \%$.

The principal has an important role in the development of the school, managing teachers, staff, and administration. Principals as leaders are required to describe educational goals, develop work plans, organize and empower themselves, delegate authority (division of tasks), communication, control / supervision and evaluation.

In this regard, the leader is able to help the employee/teacher develop patterns and improve behavior standards, and use the implementation of rules as a tool to enforce discipline. So the principal must be disciplined, both class and school yard discipline and be present every day.

One of the responsibilities of a leader is fostering teacher discipline. Discipline is very important for the teacher, because of that discipline needs to be instilled continuously. With continuous planting, the discipline becomes a habit for the teacher. People who succeed in their respective fields have high discipline, whereas people who fail are generally undisciplined, because the principal's leadership influences the teacher's work discipline.

The teacher should try to create conditions that allow students to learn actively. For example attending every set hour, formulating learning objectives, not being late for class, and so forth. The role of the teacher determines his position as an educational leader among students in the class.

From the results of the study showed that work motivation has a significant effect on teacher discipline. This result also supports the proposed hypothesis where work motivation has a significant effect on teacher discipline.

Triana research results (2016) showed that there is an influence between work motivation on teacher work discipline. This is based on the simple linear regression results namely $\mathrm{Y}=$ $24,142+0,298 \mathrm{X}$. The Effect of Work Motivation on Work Discipline of Teachers of SMA Negeri 2 Pekanbaru can be seen from the regression coefficient in which the direction of the relationship looks positive which means if work motivation increases by 1 unit then work discipline obtained by 0.298 units. From the results of the $F_{\text {test }}$ with alpha of $5 \%$, the $F_{\text {table }}$ was 4.01, while the $F$ count was 26.667. So $F_{\text {arithmetic }}>F_{\text {table }}=26,667>4.01$, which means that work motivation has a significant effect on the work discipline of teachers of SMA Negeri 2 Pekanbaru. Whereas Saputra (2017), the results of the summary model with predictors 
Volume 1 (1) 2020

E-ISSN: 2723-6919

(constant) of work motivation are seen where the value of $\mathrm{R}$ is also called the correlation coefficient is 0.461 meaning that the correlation coefficient is marked (+) positive means that it has a direct relationship. The value of $\mathrm{R}$ square $(\mathrm{R} 2)$ is 0.226 which means that the influence of work motivation on work discipline is $22.6 \%$. The better motivation possessed by an employee will be reflected in the discipline of the employee. Good work results are certainly based on good motivation too. Conversely, if the employee's work motivation is not well developed, it will lead to careless work outcomes and may threaten the achievement of organizational goals, therefore it is expected that the department especially the youth and sports service in Riau province will continue to provide motivation to its employees in improving work discipline.

Hasibuan (2010) argues, someone who has work motivation, will be able to encourage enthusiasm, uphold discipline, improve the atmosphere of a good working relationship. It is expected that teachers who have high work motivation will be more disciplined in carrying out their duties and obligations than teachers who have low motivation.

\section{Conclusion}

Based on the results of data analysis, it can be concluded 1) there is a significant positive influence of the Principal's leadership on teacher discipline. If the leadership of the headmaster is good, the teacher's work discipline is good, on the contrary if the headmaster's leadership is not good then the teacher's discipline is not good or undisciplined. The magnitude of the influence of school principal leadership on teacher discipline by contributing $27.43 \%$; 2) there is a significant positive effect of teacher work motivation on teacher discipline If the teacher has a high work motivation the influence on teacher discipline is high otherwise if the teacher's work motivation is low then the teacher's discipline decreases. The magnitude of the effect of teacher work motivation on teacher discipline by contributing $71.71 \%$; 3) there is an influence between the principal's leadership and work motivation simultaneously on teacher discipline. If the principal's leadership and teacher's work motivation is higher than the teacher's discipline is higher or increasing, conversely if the principal's leadership and teacher's work motivation decreases the teacher's discipline decreases. The magnitude of the influence of school principal leadership and teacher work motivation on teacher discipline by contributing $32.67 \%$.

\section{E. Acknowledgement}

We would like to express our special thanks and gratitude to Rector Universitas PGRI Palembang and Universitas Bengkulu who gave us the support to do this wonderful project. This project was funded independent. Secondly, we would also like to thank our friends in management of education Universitas PGRI Palembang who helped us a lot in finalizing this project within the limited time frame.

\section{REFERENCE}

Daryanto. (2006). Administrasi Pendidikan [Education administration]. Jakarta: Rineka Cipta. 
Journal of Social Work and Science Education

Volume 1 (1) 2020

E-ISSN: 2723-6919

Hadiyanto. (2004). Mencari Sosok Desentralisasi Manajemen Pendidikan di Indonesia [Looking for a Decentralized Figure in Education Management in Indonesia]. Jakarta: Rineka Cipta.

Komariah, A., \& Triatna, C. (2006). Visionary Leadership Menuju Sekolah Efektif [Visionary Leadership Towards Effective Schools]. Bandung: Bumi Aksara.

Kristiawan, M. Safitri, D., \& Lestari, R. (2017). Manajemen Pendidikan [Education Management]. Yogyakarta: Deepublish.

Law. (2003). National Education System

Nawawi, H. (1982). Organisasi Sekolah dan Pengelolaan Kelas [School Organization and Class Management]. Jakarta: Gunung Agung

Presidential Regulation No. 19 of 2005.

Siagian, S. P. (2002). Kiat Meningkatkan Produktivitas Kerja [Ways to Increase Work Productivity]. Jakarta: Rineka Cipta.

Suderadjat, H. (2005). Manajemen Peningkatan Mutu Berbasis Sekolah [School-Based Quality Improvement Management]. Bandung: Cipta Cekasa Grafika.

Syafaruddin. (2002). Manajemen Mutu Terpadu dalam Penefdidikan, Konsep, Strategi dan Aplikasi [Integrated Quality Management in Education, Concepts, Strategies and Applications]. Jakarta: Grasindo.

Trisnamansyah, S. (2007). Metodologi Penelitian Kualitatif dan Kuantitatif [Qualitative and Quantitative Research Methodologies]. Ciamis: Unigal. 